\title{
PEMANFAATAN LIMBAH KULIT SIWALAN (BORASSUS FLABELLIFER) SEBAGAI PEWARNA ALAMI UNTUK PRODUK INTIMATES (BRA MASTEKTOMI)
}

\author{
Ananda Putri Rohalida, Kahfiati Kahdar, Yan Yan Sunarya \\ Institut Teknologi Bandung (ITB) Jawa Barat, Indonesia \\ Email: anandaptrrhld@gmail.com,kahfiati@gmail.com, yanyansunar@gmail.com
}

\begin{abstract}
Abstrak
Siwalan banyak tersebar di penjuru Indonesia, seperti Bali, Sulawesi Selatan, dan Jawa Timur. Siwalan memiliki banyak manfaat dari buah, daun, hingga serat sabutnya. Namun kulit siwalan masih kurang pemanfaatannya. Intimates fashion berbasis eco-fashion dengan menggunakan pewarna alam masih belum berkembang terutama pada pembuatan bra mastektomi, padahal peluang ini masih sangat besar mengingat tingginya jumlah kanker payudara di Indonesia. Angka penderita kanker payudara di Indonesia telah mencapai 42,1 orang per 100 ribu penduduk. Pemanfaatan limbah kulit siwalan sebagai pewarna alam untuk produk bra mastektomi ini merupakan pemenuhan kebutuhan bra masektomi dengan memberikan variasi warna dan inovasi yang lebih ramah lingkungan. Penelitian ini disusun menggunakan metode campuran. Metode lebih mengarah kepada metode kualitatif didukung dengan eksperimen yang merupakan bagian dari metode kuantitatif. Tujuan penelitian ini antara lain: (a) Menghasilkan pewarna alam melalui eksperimen dari ekstrak kulit siwalan pada kain tencel yang paling diminati calon pelanggan; (b)Menghasilkan mastektomi bra yang berbasis eco fashion melalui observasi desain intimates fashion 2023 dan preferensi warna menggunakan ekstrak kulit siwalan oleh calon pelanggan. Kebaruan pada penelitian ini antara lain: (a) Menjadikan produk tekstil dengan pewarnaan alami yang berasal dari kulit siwalan; (b) Memfungsikan material yang telah diberi pewaranaan menjadi produk mastektomi bra. Hal menghasilkan kesimpulan, yaitu: (a) Dihasilkannya produk tekstil dengan pewarna alam berasal dari kulit siwalan; (b) Hasil tersebut akan menjadi inovasi dalam bidang fashion yang lebih ramah lingkungan, masktektomi bra berbahan dasar kain tencel yang telah diwarnai akan sangat berfungsi dengan baik dan memiliki warna cantik yang ramah lingkungan.
\end{abstract}

Kata Kunci: bra mastektomi; eco-fashion; intimates; kulit siwalan

\section{Abstract}

Siwalan is spread throughout Indonesia, such as Bali, South Sulawesi, and East Java. Siwalan has many benefits from fruit, leaves, to coir fiber. However, the skin of siwalan is still underutilized. Intimate eco-fashion using natural dyes is still underdeveloped, especially in the manufacture of mastectomy bras, even though this opportunity is still very large considering the high number of breast cancers in Indonesia. The number of breast cancer sufferers in Indonesia has reached 42.1 people per 100 thousand population. The utilization of waste

$\begin{array}{ll}\text { How to cite: } & \text { Rohalida, A, P., Kahdar, K., Sunarya, Y, Y., (2022) Pemanfaatan Limbah Kulit Siwalan (Borassus } \\ & \text { Flabellifer) Sebagai Pewarna Alami untuk Produk Intimates (Bra Mastektomi), Syntax Idea, 4(1), } \\ & \text { https://doi.org/ 10.36418/syntax-idea.v4i1.1735 } \\ \text { E-ISSN: } & \text { 2684-883X } \\ \text { Published by: } & \text { Ridwan Institute }\end{array}$


siwalan's skin as a natural dye for mastectomy bra products is a fulfillment of the need for mastectomy bras by providing color variations and innovations that are more environmentally friendly. This study was structured using mixed methods. The method is more directed to the qualitative method supported by experiments which are part of the quantitative method. The objectives of this research include: (a) Produce natural dyes through experiments from siwalan's skin extract on tencel fabrics that are most in demand by potential customers; (b) Produce a mastectomy bra based on eco fashion through observation of intimates fashion 2023 design and color preference using palm tree extract by prospective customers. The novelties in this research include: (a) Making textile products with natural coloring derived from the palm bark; (b) Functioning the material that has been dyed into a mastectomy bra product. This resulted in conclusions, namely: (a) The production of textile products with natural dyes derived from the skin of the palm tree; (b) The result will be an innovation in the field of fashion that is more environmentally friendly, a mastectomy bra made from dyed tencel fabric will function very well and have beautiful colors that are environmentally friendly.

Keywords: eco-fashion; intimates; mastectomy bra; siwalan's skin

\section{Received: 2021-12-22; Accepted: 2022-01-05; Published: 2022-01-20}

\section{Pendahuluan}

Jenis tanaman palem adalah salah satu sumber daya alam yang memiliki persediaan yang cukup besar di Indonesia. Salah satu jenis Palem yang ada di Indonesia adalah Siwalan. Siwalan (Borassus flabellifer $L$ ) atau yang biasa dikenal sebagai lontar merupakan jenis Palem penghasil nira yang potensial di Indonesia. Tanaman ini cenderung dapat bertahan hidup pada lahan yang kritis. Habitat ideal untuk siwalan tumbuh yakni di dataran kering dan terbuka, dengan ketinggian 0-500 mdpl. Persebaran siwalan di Indonesia dapat dijumpai pada wilayah pantai seperti Jawa Timur (Lamongan, Gresik dan Tuban), Jawa Tengah, Madura, Bali, NTT, NTB, Maluku Tenggara dan Sulawesi Selatan (Aperti, 2018).

Pohon siwalan dapat disebut sebagai tanaman serbaguna, hal tersebut karena seluruh bagian tanaman dapat dimanfaatkan atau memiliki nilai ekonomis (Bernhard, 2007). Akar tanaman siwalan dapat digunakan sebagai bahan bakar maupun pupuk. Tulang daun hingga daun tua pun dapat dimanfaatkan sebagai bahan anyaman ataupun pendukung rumah seperti atap atau dinding. Bersamaan dengan banyaknya siwalan yang dilakukan secara berkelanjutan (sustainable), menyebabkan limbah kulit buah siwalan menumpuk. Kulit siwalan mempunyai manfaat, seperti pemnafaatn untuk pewarnaan tekstil. Kulit siwalan sendiri memiliki kandungan zat warna antosianin dan senyawa fenolik yang bersifat antioksidan, karenanya kenampakan kulit buah siwalan yang berwarna merah dan ungu. Pigmen antosianin berperan terhadap timbulnya warna merah hingga ungu, hal ini bisa dilihat pada warna bunga maupun buahnya (Muri, 2014). 
Meningkatnya persaingan dalam industri tekstil, menyebabkan adanya tuntutan terhadap variasi warna yang dibutuhkan, namun limbah zat warna sintetis dapat menimbulkan pencemaran lingkungan, sehingga pewarna alami kembali dilirik menjadi suatu alternatif. Bahan pewarna kimia dapat mencemari lingkungan serta dapat menimbulkan berbagai penyakit bagi pemakainya. Pewarna alami dapat diperoleh dari hewan dan tanaman. Pewarna alami ini memiliki pigmen yang sudah ada dalam bahan atau terbentuk ketika proses penyimpanan, pemanasan atau proses yang lainnya. Pewarna alami ini aman dan tidak menimbulkan efek samping bagi penggunanya. Aspek kurangnya pemanfaatan kulit siwalan menjadi produk yang lebih berguna utamanya pada bidang fashion untuk mendukung penelitian ini. Hal ini dilakukan untuk memberikan nilai tambah kulit siwalan menjadi pewarna tekstil. Selanjutnya produk tekstil tersebut dikembangkan menjadi produk pakaian dalam berupa bra khusus wanita yang telah menjalankan mastektomi, yang sebelumnya akan dilakukan pewarnaan menggunakan ekstrak kulit siwalan.

Pakaian dalam (intimates) berperan penting dalam kehidupan sehari-hari, karena pakaian dalam adalah pondasi dari segala pakaian yang digunakan dan kebutuhan dasar bagi setiap individu. Sejak tahun 1980, pakaian dalam bukan pakaian yang hanya dikenakan sebagai pakaian lapis pertama tetapi dapat dikenakan sebagai pakaian utama. Di Indonesia sendiri, sangat sedikit brand intimates dalam negeri, terutama pakaian dalam untuk wanita yang telah menjalankan mastektomi. Pada tahun 2016, Attika Nurul Haniya mahasiswi dari UGM dibantu oleh ketiga temannya, Ulvi Henida, Erinda Septyaningrum dan Iffa Luthfiyah merancang bra untuk wanita yang telah menjalankan mastektomi. Hal ini dilakukam untuk memunculkan kembali rasa percaya diri para wanita yang mengalami mastektomi. Namun, di Indonesia sendiri belum pernah dilakukan pembuatan bra mastektomi (bra pasca operasi) dengan bahan yang lebih sustainable.

Penelitian dari Oting Susilawati yang berjudul Pengembangan Bra Khusus Post Mastektomi Untuk Meningkatkan Kepercayaan Diri Pasien Dengan Kanker Payudara Post Mastektomi, 2019 dan penelitian Adindha Firdausa Ratnasari yang berjudul Pemanfaatan Limbah Biji Alpukat (Persea americana Mill) Sebagai Pewarna Alam untuk Produk Modest Couture, 2019, akan dijadikan acuan dalam penelitian ini. Oleh karena itu, pembuatan bra menggunakan pewarna kulit buah siwalan yang akan diaplikasikan di kain tencel dinilai tepat dalam rangka memberikan inovasi baru pada fashion khususnya pakaian dalam untuk wanita yang telah menjalankan mastektomi (bra mastektomi).

\section{Metode Penelitian}

Eksperimen dalam penelitian ini termasuk ke dalam bagian dari metode kuantitatif. Eksperimen merupakan pemberian perlakuan pada objek penelitian yang dilakukan dengan tujuan untuk menguji dan membuktikan hipotesa. Percobaan dilakukan di rumah dengan alat dan bahan yang diperlukan. Sedangkan penelitian kualitatif yang digunakan adalah berupa validasi kuisioner dan dokumentasi untuk 
memastikan kebenaran suatu informasi atau data yang diperoleh dengan mengumpulkan berbagai data melalui studi literatur dan proses validasi yang dilakukan dalam proses eksperimen.

Penelitian kualitatif dalam penelitian ini, digunakan sebagai instrumen analisa yang berasal dari peneliti. Metode penelitian kualitatif harus dilakukan secara intensif, yang artinya peneliti ikut berpartisipasi di lapangan, mencatat secara hati-hati apa yang terjadi, melakukan analisis reflektif terhadap berbagai dokumen yang ditemukan di lapangan, dan membuat laporan penelitian secara mendetail (Muri, 2014).

Dalam penelitian ini, terdapat proses eksplorasi yang lebih dekat sebagai bagian pada penelitian kualitatif dikarenakan data yang disajikan berupa gambar dan fokus pada proses eksperimen berlangsung. Eksplorasi menurut KBBI memiliki arti: penjelajahan lapangan dengan tujuan memperoleh pengetahuan lebih banyak terutama sumber-sumber alam yang terdapat di tempat itu; penyelidikan; penjajakan. Dapat diartikan tersebut eksplorasi yang dilakukan dalam penelitian ini lebih mengarah kepada penjelajahan atau kegiatan untuk memperoleh sesuatu yang baru, dalam hal ini untuk mengetahui potensi pemanfaatk kulit siwalan untuk pewarna produk bra mastektomi.

Menurut (Muri, 2014), metode penelitain kualitatif dan kuantitaif dapat digunakan bersama-sama atau digabungkan, dengan catatan salah satunya, dapat digunakan bersama untuk meneliti pada obyek yang sama, tetapi dengan tujuan yang berbeda. Metode kualitatif digunakan untuk menemukan hipotesis, sedangkan metode kuantitatif digunakan untuk menguji hipotesis tersebut. Tetapi, kedua metode ini dapat juga digunakan secara bergantian. Sehingga penelitian ini adalah penelitian yang lebih menitikberatkan pada penelitian kualitatif yang didukung dengan penelitian kuantitatif. Dikarenakan peneliti sebagai subjek pengamat utama, sedangkan penelitian kuantitaif menjadi media, cara, atau alat untuk mendukung data-data serta penelitian yang dikerjakan.

Penelitian ini terdiri dari beberapa metode pengumpulan data, diantaranya adalah, tinjauan pustaka mencakup laporan penelitian, jurnal penelitian dan buku referensi yang berkenaan dengan masalah yang diteliti yaitu, mengenai pewarnaan alam, kulit siwalan, eco-fashion, intimates dan bra mastektomi, bbservasi terhadap produk tekstil berbasis pewarna alam, serta koleksi busana couture yang sudah ada di pasaran, eksperimen warna, eksplorasi desain bra mastektomi, tahap fashion design menurut (McKelvey \& Munslow, 2011).

Data dan informasi yang diperoleh baik melalui literatur, eksperimen dan kuesioner dianalisis dengan model interaktif sebagaimana digambarkan (Erwanto, Sugiyono, Rohman, Abidin, \& Ariyani, 2012). Tahapan analisis meliputi tiga alur aktifitas sebagai suatu sistem yaitu: Reduksi data, penyajian data, dan penarikan kesimpulan.

\section{Hasil dan Pembahasan}

Dari uji preferensi terhadap calon pelanggan dapat ditarik kesimpulan bahwa preferensi warna calon pelanggan lebih menyukai pada warna kain tencel yang 
dicelupkan ke ekstrak kulit siwalan dengan proses tanpa menggunakan mordan. Untuk preferensi jenis bra dari calon pelanggan paling menyukai bra dengan jenis non wire atau tanpa kawat. Pada preferensi motif tekstil nampaknya pelanggan lebih menyukai kain motif polos. Sedangkan, preferensi design bra untuk bra mastektomi, pelanggan lebih menyukai design menggunakan zipper. Berdasarkan rangkuman tersebut, dalam proses produk akhir mengedepankan pada pilihan utama pelanggan, namun tetap memperkaya variasi dalam produknya dengan mengkombinasikan pilihan lainnya, walaupun tidak mendominasi. Sehingga dengan kata lain, pilihan terbanyak digunakan untuk menentukan tingkat dominansi produksi. Walaupun pilihan calon pelanggan berada pada tingkat terbanyak kedua atau ketiga yang tetap diproduksi dengan skala yang lebih kecil. Hal ini dimaksudkan untuk memperkaya variasi teknik produksi, dengan tanpa meninggalkan preferensi calon pelanggan.

1. Proses Fashion Design

Proses fashion design ini dengan alasan memudahkan dalam analisis, dibagi ke dalam tiga sub Bab, yang secara berutuan sebagai berikut : 1) Image board, 2) Sketsa prototipe produk, dan 3) Produksi prototipe produk. Masing-masing dijabarkan di bawah ini.

2. Image Board

Image board mengedepankan nilai keberlanjutan (sustainability) tanpa mengurangi fungsi dan tujuan. Terinspirasi dari bentuk kelopak buah siwalan yang bertumpuk, nantinya akan dijadikan cutting atau potongan dalam produk. Siluet basic dan warna warm neutrals akan cocok disegala jenis selera dan warna kulit. Produk yang dirancang berjudul SiWiseLand yang terinspirasi dari material pewarna utama yang digunakan yaitu ekstrak kulit siwalan dengan desain yang bijaksana saat dijadikan produk intimates, khususnya bra mastektomi.

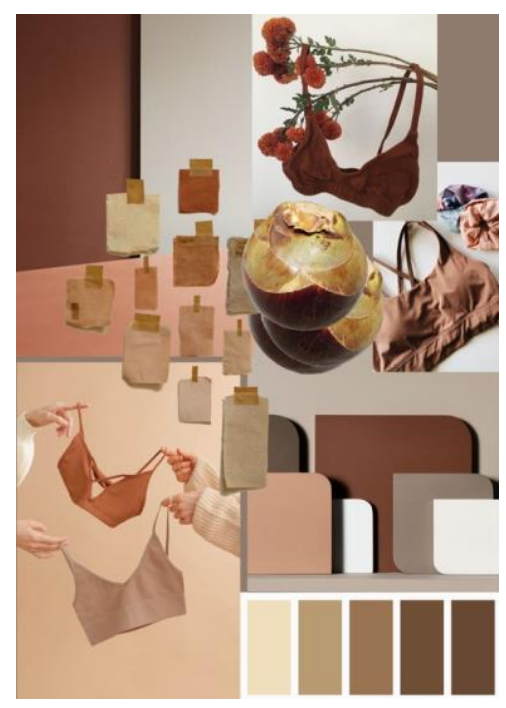

Gambar 1

Image board "SiWiseLand"

Sumber; Peneliti, 2021 
3. Sketsa Prototipe Produk

Sketsa untuk prototipe produk dibuat dengan menggunakan program Adobe Illustrator dan Adobe Photoshop. Sketsa dibuat dengan membuat design bra dan memberi warna sesuai preferensi yang telah didapat, sehingga dihasilkan gambaran yang cukup jelas apabila produk diproduksi, hasilnya akan menjadi seperti apa. Sketsa produk yang dibuat yaitu sebagai berikut:
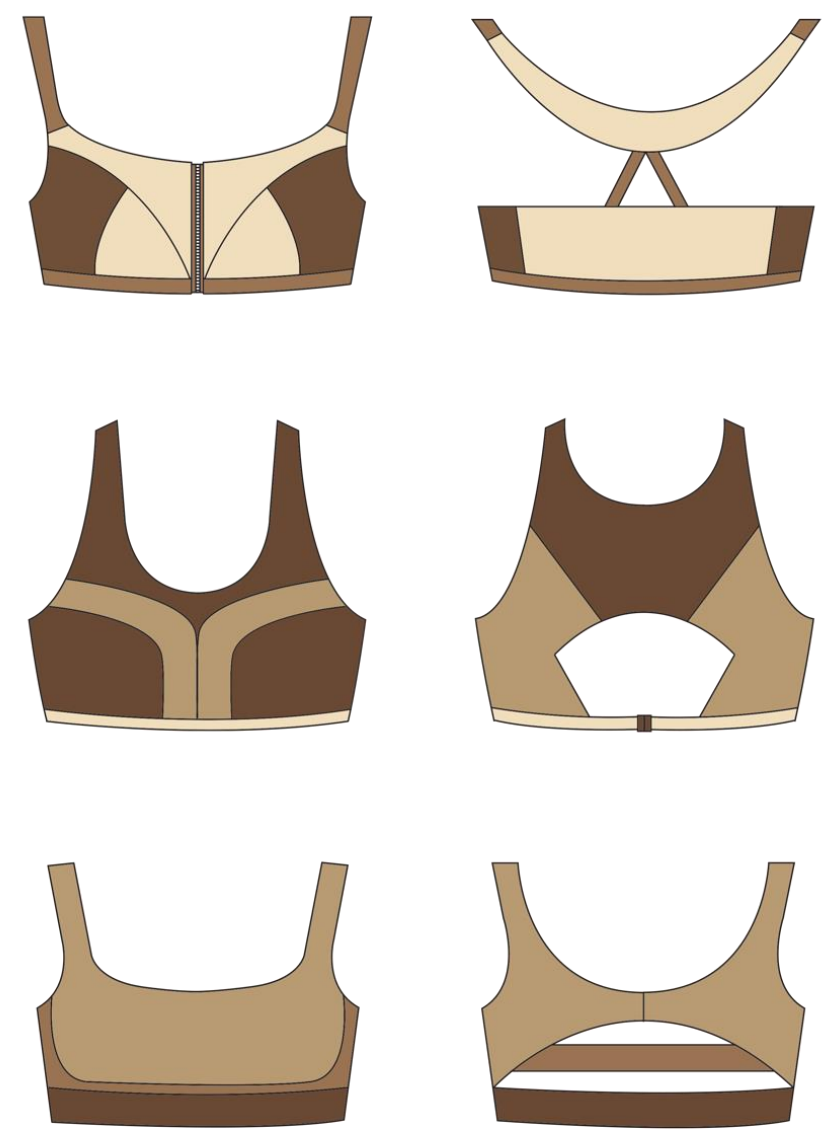

\section{Gambar 2}

Design bra koleksi "SiWiseLand" (Sumber: Peneliti, 2021)

\section{Produksi Prototipe Produk}

Setelah eksperimen dan uji minat untuk preferensi selesai dilakukan, seluruh kain tencel dilakukan pewarnaan menggunakan ekstrak kulit siwalan yang dikerjakan dirumah dengan tata cara yang sama saat melakukan percobaan pada kain $3 \mathrm{~cm} \mathrm{x}$ $3 \mathrm{~cm}$. Warna yang dipilih untuk dijadikan prototipe adalah warna kulit siwalan tanpa manggunakan mordan dengan waktu pencelupan 5 menit dan 45 menit. Kain yang dicelup dengan waktu pencelupan 5 menit menghasilkan PANTONE 12-0812 TCX Alabaster Gleam sebesar setengah meter, sedangkan kain yang dicelup 45 menit menghasilkan PANTONE 18-1033 TCX Dachshund sebesar seperempat meter. Proses produksi prototipe dilakukan di rumah dengan bantuan pembuatan pola dan 
pemotongan kain yang dilaksanakan oleh Nuriska Effa di Tangerang. Proses jahit dan finishing dilakukan di rumah.

Proses produksi dalam pembuatan prototipe melalui beberapa langkah secara berurutan yaitu 1) Color dyeing (pencelupan warna), 2) Pattern \& cut (pola dan potong), 3) Sewing process (proses penjahitan), 4) Fitting (pengepasan) dan 6) Final product (produk akhir). Tahapan-tahapan tersebut dijabarkan sebagaimana di bawah ini.

5. Color dyeing (pencelupan warna)

Proses produksi diawali dengan melakukan pencelupan warna dengan menggunakan ekstrak kulit siwalan. Kain tencel dan karet dicelupkan ke dalam bejana stainless steel yang berisi ekstrak kulit siwalan. Kain yang dibutuhkan sebesar $3 / 4$ meter dibagi menjadi dua warna yang dipilih. Kain $1 / 2$ meter untuk warna PANTONE 12-0812 TCX Alabaster Gleam dan 1/4 meter untuk PANTONE 18- 1033 TCX Dachshund. Waktu untuk pencelupan kain dilakukan sesuai kebutuhan warna yang di butuhkan, yaitu 5 menit dan 45 menit. Dari hasil pencelupan menunjukan warna pada kain dan karet telah dicelup menghasilkan warna yang berbeda. Pada karet warna yang dihasilkan kecoklatan, namun tidak merata sedangkan, pada kain, warna yang dihasilkan dari pencelupan merata.

6. Pattern \& Cut (pola dan potong)

Pembuatan pola bra dilakukan di Batu Ceper, Tangerang, dibantu oleh Nursika Effa. Setelah pola dibuat maka akan dilakukan pemotongan kain tencel. Material utama yaitu bahan tencel dipotong setelah kain di celup, hal ini bertujuan agar warna yang dihasilkan merata nantinya. Proses pemotongan dilakukan dengan cara meletakkan kertas pola yang telah dibuat sesuai dengan desain dan ukuran yang ditentukan di atas kain tencel.

7. Sewing process (proses penjahitan)

Tahap ketiga setelah kain dipotong, bahan tencel dijahit sesuai dengan pola dan ukuran yang telah ditentukan menggunakan kaidah jahitan intimates pada buku Sewing Lingerie that Fits: Stylish Underwear, Sleepwear, and Loungewear for Everyday Living yang dilakukan secara seksama untuk menghindari kerusakan teknis, yang kemungkinan berpengaruh terhadap produk akhir. Pertama-tama, satukan potongan-potongan kain yang membentuk cup.

8. Fitting (Pengepasan)

Menurut (Krajka, 2001), fitting adalah cocok atau tepat untuk suatu event, dengan kata lain proses mengepas busana sebelum busana selesai dan resmi digunakan. Fitting dilakukan agar melihat ukuran dan cutting sudah sesuai dengan desain. Dalam penelitian ini setelah dilakukan fitting secara keseluruhan tidak ada perubahan sama sekali. Fitting dilakukan dua kali, bersama salah satu responden yang pernah melakukan mastektomi dan responden yang lainnya yang belum pernah melakukan mastektomi. Hal ini dilakukan agar produk bra mastektomi yang dibuat tidak hanya dipakai oleh wanita yang pernah menjalankan mastektomi saja, melainkan dapat dipaka oleh wanita dengan payudara sehat dan normal. 


\section{Finish Product (Produk Akhir)}

Produk akhir merupakan hasil dari seluruh tahapan produksi. Busana yang direalisasikan menghasilkan satu bra mastektomi sesuai dengan design yang dibuat dan preferensi warna yang dipilih. Produk akhir dibuat berdasarkana kaidah intimates dari hasil penelitian (Susilawati \& Santosa, 2019). Tata cara pembuatan produk akhir pun mengikuti cara sistematis dari buku Bare Essentials: Bras - Third Edition: Construction and Pattern Design for Lingerie Design yang disusun oleh Jennifer Lynne Matthews yang merupakan bagian akhir dari seluruh tahapan proses produksi.

\section{Kesimpulan}

Berdasarkan temuan penelitian,maka didapatkan bahwa limbah kulit siwalan dapat dimanfaatkan sampai pada penemuan 20 warna tanpa mordan dan menggunakan 3 jenis mordan, yaitu; jeruk nipis, kapur sirih, dan tawas melalui eksperimen warna. Hasil penelitian melalui eksperimen warna dengan ekstrak kulit siwalan pada kain tencel dengan menggunakan konsentrasi 800 gram kulit siwalan dalam $800 \mathrm{ml}$ air direbus pada suhu $65^{\circ} \mathrm{C}$ pada durasi pencelupan $5,15,30,45$, dan 60 menit menghasilkan 5 gradasi warna dari terang ke gelap dari setiap percobaan. Warna Pantone dari 12-0812 TCX Alabaster Gleam, 16-1324 TCX Lark, 17-1327 TCX Tobacco Brown, 18- 1033 TCX Dachshund, dan 18-1028 TCX Emprador adalah warna-warna yang paling diminati oleh calon pelanggan berdasarkan hasil uji preferensi warna. Setelah itu, metode postmordanting menggunakan mordan jeruk nipis kosentrasi $5 \mathrm{ml} /$ liter menghasilkan 4 gradasi warna yang lebih cerah dibandingkan hasil warna ekstrak kulit siwalan tanpa mordan. Demikian juga pada perlakuan sama dengan mordan tawas menghasilkan 4 gradasi warna yang lebih terang pucat hingga gelap dibandingkan dengan warna yang tanpa mordan. Namun pada perlakuan yang sama menggunakan mordan kapur sirih, warna yang dihasilkan lebih tua dan kecoklatan dibandingkan tidak memakai mordan dan mordan jeruk nipis dan tawas. Warna kain tencel yang memiliki warna gelap dan pucat (memakai mordan jeruk nipis, tawas dan kapur sirih cenderung kurang diminati dibandingkan warna dengan kain tanpa mordan yang terlihat lebih cerah dan berwarna). Hasil perancangan intimates bra masektomi dimulai dengan observasi desain pada Intimates Forecast S/S 2023 yaitu siluet dan desain bra. Selanjutnya, perancangan dilanjutkan berdasarkan uji preferensi pada 72 orang responden, ditemukan preferensi warna, jenis bra, motif tekstil dan design bra. Jenis bra yang diminati adalah jenis bra tanpa wire. Terhadap preferensi motif tekstil calon pelanggan lebih tertarik pada motif yang polos. Sedangkan dari sisi desain calon pelanggan lebih menyukai desain bra dengan menggunakan zipper.Koleksi intimates bra masektomi berjudul SiWiseLand dibuat berdasarkan preferensi calon pelanggan tersebut dan Intimates Forecast S/S 2023. Dalam proses produksi prototipe terutama penjahitan, dilakukan berdasarkan kaidah dalam pembuatan produk intimates yang sudah diketahui. Setelah dievaluasi, produk berbahan dasar tencel memang merupakan kain yang harus diproduksi dengan penuh kehati-hatian sebab kain ini termasuk kain yang sangat lembut dan menyusut apabila direbus saat pencelupan. 


\section{BIBLIOGRAFI}

Aperti, Admin. (2018). Studi Potensi Pemanfaatan Limbah Serat Batok Siwalan (Borassus Flabellifer L) sebagai Bahan Baku Kerajinan Lokal (Benang) Gresik. Jurnal Teknologia, 1(1), 79-88.Google Scholar

Bernhard, Maliangkay Ronny. (2007). Teknik budidaya dan rehabilitasi tanaman aren. Buletin Palma, (33), 67-77. Google Scholar

Erwanto, Yuny, Sugiyono, Sugiyono, Rohman, Abdul, Abidin, Mohammad Zainal, \& Ariyani, Dwi. (2012). Identifikasi daging babi menggunakan metode pcr-rflp gen Cytochrome b dan pcr primer spesifik gen amelogenin. Agritech, 32(4). Google Scholar

Gho, S.A., Munro, B.J., Jones, S.C. \& Steele, J.R. (2014). Evidence-based recommendations for building better bras for women treated for breast cancer. Ergonomics, 57(5), 774-786. Google Scholar

Komang, Ni. Fatarina, Ery. (2016). Pengembangan Optimalisasi Ekstrasi Antosianin Kulit Buah Siwalan Warna Ungu dan Diimplementasikan Sebagai Pewarna Alami Pada Kain Katun Secara Pre-Mordating, Jurnal Sains dan Teknologi SNST Vol 1 No 1, Fakultas Teknik, Universitas Wahid Hasyim. ISBN 978-602-99334-5-1. Semarang. Google Scholar

Krajka, Jarek. (2001). Oxford Advanced Learner's Cd-Rom Dictionary. Teaching English with Technology, 1(5), 23-30. Google Scholar

Matthews, Jennifer Lynne. (2019). Bare Essentials: Bras - Third Edition: Construction and Pattern Design for Lingerie Design. Fairbanks Publishing LLC dba Porcelynne.

Muri, Yusuf. (2014). Metode Penelitian, Kuantitatif, Kualitatif, Dan Penelitian Gabungan. Jakarta. Prenadia. Google Scholar

McKelvey, Kathryn, \& Munslow, Janine. (2011). Fashion design: process, innovation and practice. John Wiley \& Sons. Google Scholar

Ratnasari, Adhindha Firdausa. (2019). Pemanfaatan Limbah Biji Alpukat (Persea americana Mill) Sebagai Pewarna Alam untuk Produk Modest Couture, Institut Teknologi Bandung.

Saxena, S., and Raja, A.S.M. (2014): Natural Dyes: Sources, Chemistry, Application and Sustainability Issues. In: Muthi, S.S., (eds) Roadmap to Sustainable Textiles and Clothing, Spinger Science, Singapore. Google Scholar

Sugiyono. (2014). Metode Penelitian Pendidikan Pendekatan Kuantitatif, Kualitatif, dan R\&D. Bandung: Alfabeta. Google Scholar 
Ananda Putri Rohalida, Kahfiati Kahdar, Yan Yan Sunarya

Susilawati, Oting, \& Santosa, Agus. (2019). Innovative post mastectomy bra for increasing self-convenience and confidence patients. Google Scholar

Senthilkumar, RP., Bhuvaneshwari, V., Sathiyavimal, S., Amsaveni R., Kalaiselvi, M., Malayaman, V. (2015): Natural Colours from Dyeing Plants for Textiles. International Journal of Biosciences and Nanosciences. Vol. 2(7). 160- 174. Google Scholar

Vithanage, C.P. \& Subodha, U. (2013). Introducing a high-tech mastectomy bra to Sri Lankan market. International Journal of Research in Medical and Health Sciences, 1(2), 16-23. Google Scholar

WGSN. (2021). Fashion Intimates Forecast S/S 2023. Diambil Oktober, 2021: https://www.wgsn.com/en.

Copyright holder:

Ananda Putri Rohalida, Kahfiati Kahdar, Yan Yan Sunarya (2022)

First publication right:

Syntax Idea

This article is licensed under:

(c) (i) (?) 